\title{
ANTIOXIDANT AND ANTIBACTERIAL ACTIVITIES OF NON- POLAR TO POLAR SOLVENT EXTRACTS OF Sarang Banua (Clerodenrum fragrans Vent Willd) LEAVES
}

\author{
M. Simorangkir*, W. Hutabarat, B. Nainggolan and S. Silaban \\ Department of Chemistry, Universitas Negeri Medan, Medan 20221, Indonesia \\ *E-mail : murniatysimorangkir@unimed.ac.id
}

\begin{abstract}
Sarangbanua plant, known as Clerodendrumfragrans Vent Willd, is a division of the Verbanaceae family found in Simalungun district of Indonesia, which is traditionally used as medicinal plants. The antioxidant and antibacterial activities of the $C$. fragrans leave extract was prepared by dissolving it in non-polar to polar solvents and treated by DPPH (1,1-diphenyl-2-picrylhydrazin) and diffusion methods. The results showed that the ethanol (polar) extract of the $C$. fragrans leaves had the highest antioxidant activity than ethyl acetate (semi-polar) and $n$-hexane (non-polar) extracts, which had $\mathrm{IC}_{50}$ values of $22.37 \mathrm{ppm}, 27.26 \mathrm{ppm}$, and $88.77 \mathrm{ppm}$ respectively. Vitamin $\mathrm{C}$ as a positive controlled with the $\mathrm{IC}_{50}$ value of $20.18 \mathrm{ppm}$. Furthermore, the ethyl acetate (semi-polar) extract of the $C$. fragrans leaves had the greatest inhibition value on Gram-positive bacteria of S. aureus (90.0\%)with inhibitory zones of $11.25 \pm 0.2 \mathrm{~mm}$, meanwhile the $n$-hexane (non-polar) extract had the greatest inhibition against Gram-negative bacteria of the E.coli(77.21\%)with inhibitory zones of $10.5 \pm 0.3 \mathrm{~mm}$.

Keywords: Clerodendrum fragrant Vent Willd, Antibacterial, Antioxidant, Polarity of solvent, Medicinal plant of Indonesian.
\end{abstract}

(C) RASĀYAN. All rights reserved

\section{INTRODUCTION}

It is known that Genus Clerodendrum (Family of Verbanaceae) has more than five hundred species which are semi-woody shrubs and widespread in the tropics regions. The root, stem and leaf extracts of the Clerodendrum species have been used traditionally for the treatment of asthma, cataracts, malaria, blood, skin and lung diseases, rheumatism, inflammatory, cough, genital infections, skin diseases, anti-diabetic, anti-hypertensive, sedative, antibacterial, analgesic and antioxidant ${ }^{1,2}$. One species of the clerodendrum is found in Raya Usang village, Simalungun district, North Sumatera Indonesia, which is typically shrubs and grows to around 2.5-3.0 m high, it has whitish pink flowers and the flower petal is reddish purple in color and 10-15 mm in length, the leaves are simple and opposite, oval and its length 6-25 cm and 5-25 $\mathrm{cm}$ wide and the edges of the leaves are wavy. Local people call it "Sarangbanua" as shown in Fig. -1. Base on the herbarium determination carried out by the "Herbarium Bogorinse" Botanical Field of the Biology Research Center-LIPI Bogor, the plant is classified as a type of the Clerodenrumfragrans Vent Willd which is a division of the Verbanaceae family and has been stored as herbarium form "Herbarium Bogoriense" in June 2017. Generally, the local community uses it as traditional medicinal plants.

The medicinal plants are known as pharmaceutical sources and rich in active secondary metabolites such as alkaloids, steroids, flavonoids, tannins, saponins and phenol compounds, which are available at low cost and easily decomposed. For instance, Clerodenrumvolubile plant could be used as an analgesic and containing chemical compounds suchas saponins, tannins, anthraquinones, flavonoids, alkaloids, phenols, terpenes and glycosides ${ }^{2}$, steroidal glycoside. Furthermore, alkaloid $\beta$-solanin from the ethanol extract of Solanumblumei Nees ex Blume fruit has toxicity and anticancer for $\mathrm{L}_{1210}$ leukemia cells ${ }^{3,4}$. Secondary metabolites of the plants can be obtained through solvent extraction based on the solubility and polarity of the metabolites. For instance, normal-hexane, ethyl acetate and ethanol solvents which have different polarities, namely non-polar, semi polar and polar with dielectric constant $\left(20^{\circ} \mathrm{C}\right)$ of $1.90,6.02$ and 22.40

Rasayan J. Chem., 12(2), 959-965(2019)

http://dx.doi.org/10.31788/RJC.2019.1225095

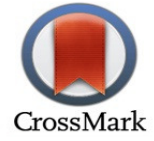


respectively ${ }^{5}$ could be used as the extraction solvents. Selection of the solvent in the maceration process is based on the principle of "likes dissolve likes" solubility, meaning that the polar compound only dissolves in polar solvents, and vice versa for semi polar and non-polar compounds.

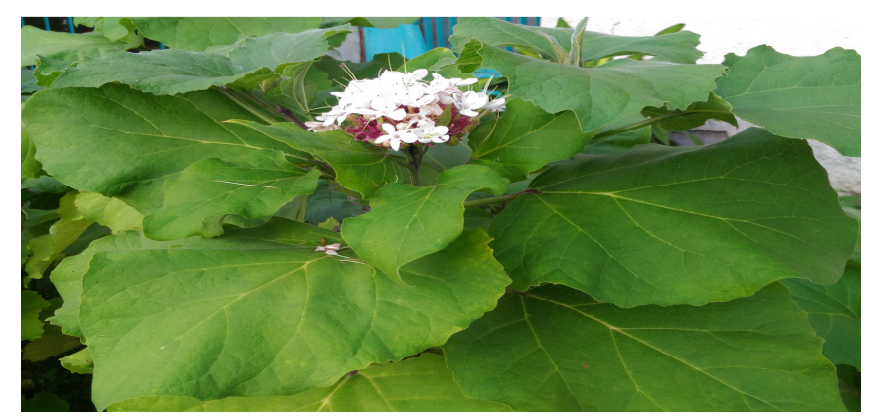

Fig.-1: Sarangbanua (Clerodendrumfragrans Vent Willd).

Qualitative phytochemicals analysis of medicinal plant extracts i.e. Boerhaaviadiffusa Linn, Terminaliabellerica Linn and Tribulusterrestris Linn using polar and non-polar solvents showed different chemical contents. The solvent is one of the most important factors affecting the chemical composition and biological activity of the plant extracts ${ }^{7,8}$. A number of the Clerodendrum plant extracts have antioxidant activity against DPPH-free radical scavenging activity and antibacterial ${ }^{9-10}$. The antioxidant of the extracts was treated by DPPH (1,1- diphenyl-2-picrylhydrazin) method ${ }^{11-13}$ and antibacterial activity tests carried out by disc diffusion methods ${ }^{14,15}$.

The secondary metabolites of alkaloid, steroid and flavonoid found in the $n$-hexane extract of the $C$. fragrans leaves, alkaloids, steroids, saponins, and tannins found in the ethyl acetate extracts and in addition alkaloids, triterpenoids, flavonoids, saponins, tannins and quinines found in ethanol extractsof the $C$. fragrans leaves ${ }^{16}$. Antioxidant and antibacterial activity tests of the $C$. fragrant extracts that using various solvent polarities need to carry out in order to find out fractions with a high antioxidant and antibacterial activities which are useful for developing and usage of the $C$. fragrans local plants for the medical ingredient.

\section{Collection of Plant Sample}

\section{EXPERIMENTAL}

Plant sample selected was the Sarangbanua (C. fragrans Vent Willd) fresh leaves, obtained from Raya Usang village, DolokMasihul sub-district, Simalungun district, North Sumatera, Indonesia. The sample was identified by the "Herbarium Bogoriense" in the Bogor LIPI-Biology Research Center.

\section{Sample Extraction}

A total of $10 \mathrm{~kg}$ freshly $C$. fragrans Vent Willd leaves were washed clean with bi-distilled water, drained, dried in air and protected from direct sunlight and mechanically grounded to a simplicia powder (1.250 $\mathrm{kg}$ ). The simplicia powder of the $C$. fragrans leaves was macerated with polar solvents, namely n-hexane solvent (non-polar), followed by ethyl acetate (semi polar) and ended with ethanol solvent (polar). A total of $1000.0 \mathrm{~g}$ of simplicia powder of the fragrans leaves were macerated with $n$-hexane solvent, filtered and the filtrate obtained was concentrated in a rotary evaporator vacuum to obtain concentrated $n$-hexane extracts. The pulp portion was macerated with ethyl acetate solvents, filtered and the filtrate was concentrated to obtain concentrated ethyl acetate extracts. Furthermore, the pulp portion was re-macerated with ethanol solvents, filtered and the filtrate was concentrated to obtain concentrated ethanol extracts.The maceration processes lasted for 48 hours, with three times solvent additions. Finally, $n$ hexane, ethyl acetate and ethanol extracts concentrated of the $C$. fragrans leaves were prepared respectively ${ }^{16}$.

\section{Antioxidant Assay}

The DPPH method (1,1 diphenyl-2-picrylhydrazyl) was used forthe antioxidants test. The solution of vitamin $\mathrm{C}$ as a positive control provided with concentrations of 5,10, 25 and 50 ppm.Furthermore, making 
DPPH $0.4 \mathrm{mM}$ solution was carried out by dissolving $15.7 \mathrm{mg}$ DPPH in methanol p.a. to a volume of 100 mL solution.

\section{Preparation of Sample Test and Positive Controlled Solutions}

An extract stock solution was provided by dissolving each $5.0 \mathrm{mg}$ of $n$-hexane, ethyl acetate and ethanol extracts of the $C$. fragrans leaves in methanol p.a. until the volume of solution is $10.0 \mathrm{~mL}$. Then, each extract solution series was made by piping $50,100,250$ and $500 \mu \mathrm{L}$ extract stock solutions into a $5 \mathrm{~mL}$ tube to obtain extract solutions of concentrations of $5,10,25$ and $50 \mathrm{ppm}$.

Then, $1.0 \mathrm{~mL}$ of DPPH $0.4 \mathrm{mM}$ solution was added to each tube and methanol p.a. to a solution volume of $5 \mathrm{~mL}$.

As a positive control, a solution of vitamin $C$ with concentrations of 5, 10, 25 and $50 \mathrm{ppm}$ was put into a $5.0 \mathrm{~mL}$ test tube, then added $1.0 \mathrm{~mL}$ DPPH $0.4 \mathrm{mM}$ and methanol p.a. to a solution volume of $5.0 \mathrm{~mL}$.As a negative control, methanol solution p.a. and $1.0 \mathrm{~mL}$ of DPPH $0.4 \mathrm{mM}$ solution in a $5.0 \mathrm{~mL}$ test tube.

All test tubes used were wrapped in aluminum foil and incubated at $37^{\circ} \mathrm{C}$ for 30 minutes, then measured absorbance with UV-Vis spectrophotometer at a wavelength of $517 \mathrm{~nm}^{11,12}$. Antioxidant testing of the sample was carried out in triplets.

The inhibition percentage was calculated by the following formula:

Inhibition $(\%)=[(A-B) / A] \times 100 \%$

Where, A is theabsorbance of the controlled negative solutions (DPPH solution without the sample), B is the absorbance of the DPPH solution in the presence of the sample (extract/ascorbic acid).

The inhibition concentration $50\left(\mathrm{IC}_{50}\right)$ value is the concentration of antioxidants $(\mathrm{ppm})$ which can inhibit $50 \%$ of free radicals. The $\mathrm{IC}_{50}$ value is obtained from the intersection of the line between $50 \%$ of the resistance power with the axis of concentrations, then put into the equation below ${ }^{13}$ :

$\mathrm{Y}=\mathrm{a}+\mathrm{bX}$

where $\mathrm{Y}=50$, and the value of $\mathrm{X}$ indicates $\mathrm{IC}_{50}$.

\section{Antibacterial Assay}

Before analysis test carried out, glassware was sterilized in an oven at $100^{\circ} \mathrm{C}$ for 2 hours. Metalwares were sterilized with a spray-mounted light, and heat-resistant appliances and the high-temperature medium were sterilized in an autoclave at $121^{\circ} \mathrm{C}$ and 2 atm for 15 minutes. Before a laminary tube is used, that is sterilized with UV light for 15 minutes and blown for 10 minutes.

A total of $3.8 \mathrm{~g}$ of Mueller Hinton Agar (MHA) was mixed homogenously with $100 \mathrm{~mL}$ aquabidest in a beaker glass and then poured into a Petri dish as a medium.

Escheria coli dan Staphylococcus aureuswere reconstructed before using in antibacterial test. The bacteria were cultured on a bend sterilized agar then incubated for 24 hours at $37^{\circ} \mathrm{C}$.The bacterial suspension was spread using a sterile cotton swab on nutrient agar plat. The turbidity of the bacterial culture was adjusted to $0.5 \mathrm{McFarlan}$ Standard then incubated for 24 hours ${ }^{19}$. Each normal-hexane, ethyl acetate and ethanol extracts were dissolved at concentrations of $0 \%, 1.25 \%, 2.50 \%, 5 \%$ and $10 \%$. Chloramphenicol discs $30 \mu \mathrm{g}$ (Oxoid) ${ }^{20}$ was used as a positive controlled. The inhibition zone of each extract is measured in $\mathrm{mm}^{17-19}$.

\section{Antioxidant Assay}

\section{RESULTS AND DISCUSSION}

Antioxidant assay of $n$-hexane, ethyl acetate and ethanol extracts of $C$. fragrans leaves was carried out by DPPH method using UV-Vis at a wavelength of $517 \mathrm{~nm}$.

The antioxidant activity of the extract can be seen from the scavenging ability of extracts against DPPH free radicals, which can be measured from DPPH color changes from purple to yellow. The reduced DPPH purple color, resulting in a smaller absorbance value, which shows the stronger scavenging activity of the extract. Ethanol extract of $C$. fragrans had the highest scavenging activity (93.2\%), followed by ethyl acetate $(88.5 \%)$ and $n$-hexane extract $(35.0 \%)$. The scavenging activity of vitamin $\mathrm{C}$ (positive 
RASĀYAN J. Chem.

Vol. 12 | No. 2 |959 - 965| April - June | 2019

control) was $97.2 \%$ (Table-1 and Fig.-2). The greater the concentration of extract, the higher the scavenging activity.

The Inhibition Concentration $50\left(\mathrm{IC}_{50}\right)$ value is the concentration of antioxidants $(\mathrm{ppm})$ which can scavenge $50 \%$ of free radicals. A compound is said to have very strong antioxidant activity value if the $\mathrm{IC}_{50}$ value is less than $50 \mathrm{ppm}$, the strength of antioxidant value for $\mathrm{IC}_{50}$ is $50-100 \mathrm{ppm}$ and the antioxidant is considered moderate if the $\mathrm{IC}_{50}$ valueranges from $101-150 \mathrm{ppm}$, and the antioxidant is classified as weak if the $\mathrm{IC}_{50}$ value ranges from 151-200 $\mathrm{ppm}^{20}$. The results showed that ethanol extract of the $C$. fragans leaves had the lowest $\mathrm{IC}_{50}$ value $(22.37 \mathrm{ppm})$ than ethyl acetate extract $(27.26 \mathrm{ppm})$ and $n$ hexane extract $(88.77 \mathrm{ppm})$, which relatively close to the $\mathrm{IC}_{50}$ vitamin $\mathrm{C}$ value as a positive controlled (20.18) (Table-1). It shows that ethanol extract of the $C$. fragrans leaf has the highest antioxidant activity value followed by ethyl acetate and $n$-hexane extracts, which are relatively close to the antioxidant activity of the Vitamin $\mathrm{C}$.

The smaller the $\mathrm{IC}_{50}$ value indicates the higher the antioxidant activity value. The antioxidant activity of the ethanol extract and ethyl acetate of the $C$. fragrans leaves found at the category of very strong which were located at a value of $<50$, while $n$-hexane extracts found at the strong antioxidant category at the 50100 region. The $\mathrm{IC}_{50}$ value of vitamin $\mathrm{C}$ as a positive controlled was $20.18 \mathrm{ppm}$ considered as a very strong antioxidant category (Table-1 and Fig.-2). The study found that the findings are highly likely similar to the findings found in the antioxidant activity test of the ethanol extract of walnut Juglansregia $\mathrm{L}$ green husk which is higher than ethyl acetate and $n$-hexane extracts and contain more total polyphenols and flavonoids ${ }^{7}$ andEugenia uniflora L's ethyl acetate extract has a higher antioxidant activity value than $n$-hexane and water fractions ${ }^{15}$.

Table.-1: Scavenging Activity of the Clerodendrumfragrans Vent Willd Leaf Extracts on DPPH

\begin{tabular}{|c|c|c|c|c|c|}
\hline $\begin{array}{l}\text { Leaf Extracts of } \\
\text { C. fragrans }\end{array}$ & $\begin{array}{c}\text { Concentration } \\
(\mathrm{ppm})\end{array}$ & Absorbance & $\begin{array}{l}\text { Scavenging } \\
\text { Activity on } \\
\text { DPPH (\%) }\end{array}$ & $\mathrm{IC}_{50}(\mathrm{ppm})$ & $\begin{array}{l}\text { Category of } \\
\text { Antioxidant }\end{array}$ \\
\hline \multirow{4}{*}{$\begin{array}{c}n \text {-Hexane } \\
\text { Extract }\end{array}$} & 5 & 0.452 & 15.5 & \multirow[t]{4}{*}{88.77} & \multirow{4}{*}{$\begin{array}{c}\text { Strong } \\
\text { Antioxidant }\end{array}$} \\
\hline & 10 & 0.424 & 20.7 & & \\
\hline & 25 & 0.413 & 22.8 & & \\
\hline & 50 & 0.229 & 35.0 & & \\
\hline \multirow{4}{*}{$\begin{array}{l}\text { Ethyl Acetate } \\
\text { Extract }\end{array}$} & 5 & 0.234 & 54.5 & \multirow[t]{4}{*}{27.26} & \multirow{4}{*}{$\begin{array}{l}\text { Very Strong } \\
\text { Antioxidant }\end{array}$} \\
\hline & 10 & 0.105 & 80.4 & & \\
\hline & 25 & 0.086 & 83.9 & & \\
\hline & 50 & 0.060 & 88.5 & & \\
\hline \multirow[t]{4}{*}{ Ethanol Extract } & 5 & 0.223 & 58.3 & \multirow[t]{4}{*}{22.37} & \multirow{4}{*}{$\begin{array}{l}\text { Very Strong } \\
\text { Antioxidant }\end{array}$} \\
\hline & 10 & 0.122 & 77.2 & & \\
\hline & 25 & 0.063 & 88.2 & & \\
\hline & 50 & 0.036 & 93.2 & & \\
\hline \multirow[t]{4}{*}{ Vitamin C } & 5 & 0.198 & 93.86 & \multirow[t]{4}{*}{20.18} & \multirow{4}{*}{$\begin{array}{l}\text { Very Strong } \\
\text { Antioxidant }\end{array}$} \\
\hline & 10 & 0.153 & 72.08 & & \\
\hline & 25 & 0.056 & 89.41 & & \\
\hline & 50 & 0.015 & 97.26 & & \\
\hline
\end{tabular}

The use of types of solvents at different polarity levels were carried out to obtain extracts that contain unknown compounds, such as in the ethyl acetate extract of the leaves of Clerodendrumphlomidis L. found steroids, alkaloids, phenols, amino acids, and no saponins, sugars, flavonoids and catachins ${ }^{21}$, meanwhile in ethanol extract found steroids and phenols. However, the crude ethanol extract of the Cleodendrumphilippinum leaves contained alkaloids, saponin, glycoside, phenolics, tannin, flavonoids, fixed oil and fats ${ }^{22}$.The ethanolic extract of roots of Clerodendrumphlomidis $\mathrm{L}$ has the highest free radical scavenging activity than the other three extracts, namely petroleum ether, chloroform and ethyl acetate $^{21}$. The polar solvent exhibited the highest amount of bioactive compounds. ${ }^{23}$ The antibacterial activity value of the $n$-hexene (non-polar), ethylacetate (semi-polar) and ethanol (polar) extracts of the $C$. 
fragrans leaves at a concentration of $1.25 \%$ to $10 \%$ indicated by the diameter of the inhibition zone against Staphylococcus aureus and Escherichia coli (Table-2).

The ethyl acetate (semi-polar) extract of the $C$. fragrans has the largest inhibition zone $(11.25 \pm 0.2 \mathrm{~mm})$ than the polar extract of the ethanol $(9.40 \pm 0.1 \mathrm{~mm})$ and non-polar $n$-hexane $(9.0 \pm 0.1 \mathrm{~mm})$ against Staphylococcus aureus(Table-2). Likewise the Escherichia coli, the ethyl acetate extract has the largest inhibition zone $(14.8 \pm 0.5 \mathrm{~mm})$ than the $n$-hexane $(10.5 \pm 0.3 \mathrm{~mm})$ and ethanol extracts $(10.2 \pm 0.2 \mathrm{~mm})$.

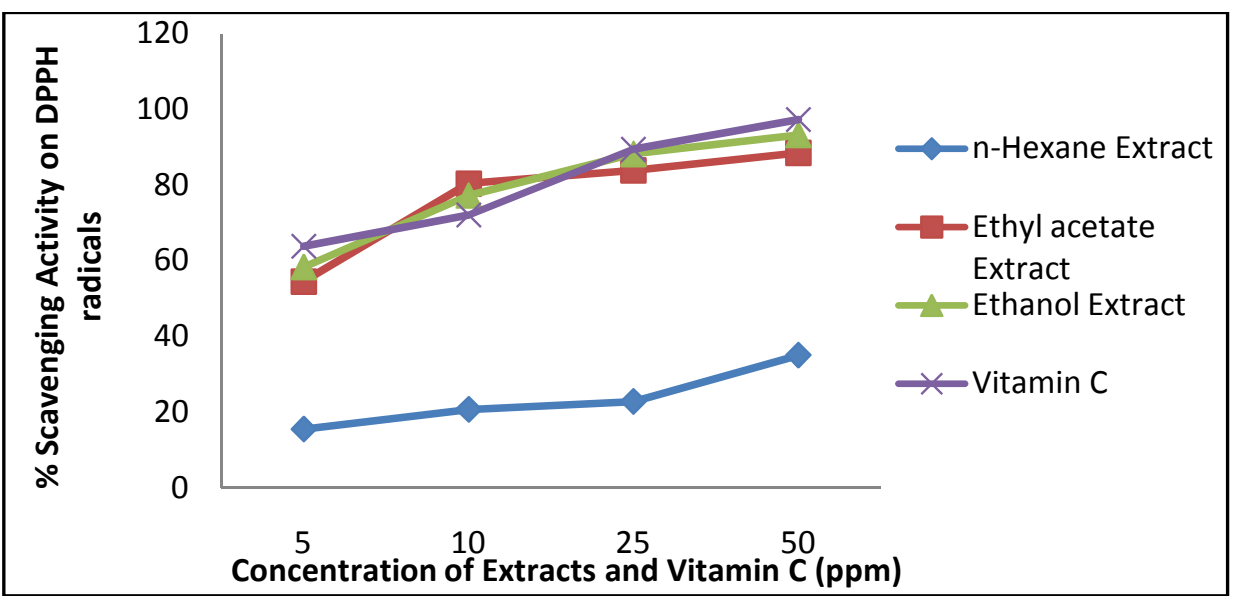

Fig.-2: Scavenging Activity of C. Fragrans Extracts Leaves On DPPH Radicals.

Table.-2: Zone of Inhibition and Inhibition Power Leaf Extracts of the C. fragrans Against Bacteria (mm).

\begin{tabular}{|c|c|c|c|c|c|c|c|}
\hline \multirow[t]{4}{*}{ Bacteria } & \multirow{4}{*}{$\begin{array}{c}\text { Plant } \\
\text { Extracts }\end{array}$} & \multicolumn{6}{|c|}{ Antibacterial Activity } \\
\hline & & \multicolumn{5}{|c|}{ The diameter of zone of inhibition $(\mathrm{mm})$} & \multirow{3}{*}{$\begin{array}{l}\text { Inhibition } \\
\text { Power (\%) }\end{array}$} \\
\hline & & \multirow{2}{*}{$\begin{array}{c}\text { Chloramphenicol } \\
\text { Disc (Oxoid) }\end{array}$} & \multicolumn{4}{|c|}{ The concentration of Extract (\%) } & \\
\hline & & & $1.25 \%$ & $2.5 \%$ & $5 \%$ & $10 \%$ & \\
\hline \multirow[t]{3}{*}{ S. aureus } & $\begin{array}{c}n \text {-Hexane } \\
\text { Exract }\end{array}$ & 19.8 & $8.40 \pm 0.4$ & $8.75 \pm 0.2$ & $8.9 \pm 0.1$ & $9.0 \pm 0.1$ & 45.45 \\
\hline & $\begin{array}{c}\text { Ethyl } \\
\text { Acetate } \\
\text { Extract }\end{array}$ & 12.5 & $9.0 \pm 0.2$ & $9.3 \pm 0.4$ & $9.7 \pm 0.2$ & $11.25 \pm 0.2$ & 90.00 \\
\hline & $\begin{array}{l}\text { Ethanol } \\
\text { Extract }\end{array}$ & 13.4 & $7.9 \pm 0.5$ & $8.6 \pm 0.6$ & $8.9 \pm 0.4$ & $9.40 \pm 0.1$ & 70.15 \\
\hline \multirow[t]{3}{*}{ E. coli } & $\begin{array}{c}n \text {-Hexane } \\
\text { Extract }\end{array}$ & 13.6 & $7.5 \pm 0.5$ & $8.9 \pm 0.5$ & $9.8 \pm 0.2$ & $10.5 \pm 0.3$ & 77.21 \\
\hline & $\begin{array}{c}\text { Ethyl } \\
\text { Acetate }\end{array}$ & 24.2 & $7.6 \pm 0.2$ & $9.2 \pm 0.2$ & $\begin{array}{c}10.1 \pm 0 . \\
2\end{array}$ & $14.8 \pm 0.5$ & 61.16 \\
\hline & $\begin{array}{l}\text { Ethanol } \\
\text { Extract }\end{array}$ & 20.3 & $7.5 \pm 0.2$ & $8.4 \pm 0.1$ & $\begin{array}{l}10.1 \pm 0 . \\
5\end{array}$ & $10.2 \pm 0.2$ & 50.25 \\
\hline
\end{tabular}

Based on the inhibitory power of chloramphenicol positive control compounds, it was found that the greatest inhibition of $C$. fragrans leaf extract against $S$. aureus was on ethyl acetate extract (90.0\%) followed by ethanol $(70.15 \%)$ and $n$-hexane extracts $(45.45 \%)$, but for E.coli, the greatest inhibition was found in $n$-hexane extract $(77.21 \%)$ followed by ethyl acetate $(61.16 \%)$ and ethanol extracts $(50.25 \%)$.

The ethyl acetate (semi-polar) extract of the $C$. fragrans leaves has the greatest inhibition value on Grampositive bacteria of $S$. aureus $(90.0 \%)$,meanwilen-hexane (non-polar) extract has the greatest inhibitory power against Gram-negative bacteria of the E.coli (77.21\%).In the $n$-hexane extract of the $C$. fragransfound secondary metabolites such as alkaloid, steroid and flavonoid metabolites, in the ethyl acetate extract found alkaloids, steroids, saponins and tannins and in ethanol extract found alkaloids, triterpenoids, flavonoids, saponins, tannins and quinines ${ }^{16 .}$ 
In contrast, it was found that methanol (polar) extract of the Curcuma aeruginosa rhizome is active against Gram-negative bacteria the $E$. coli and not active against the Gram-positive $S$ aureus bacteria ${ }^{15}$ and furthermore it was found that the non polar (pet.ether) fraction of the Brassiganigra seed has stronger antibacterial activity than crude methanol extract against the $S$. aureus bacteria ${ }^{24}$. Ethanol extract of Crinum asiaticum also has antibacterial activity against the $S$. aureus and the E. coli bacteria ${ }^{25}$. The results indicated that the solvent polarity of $n$-hexane, ethyl acetate and ethanol extracts of the $C$. fragrans leaves are associated with the antioxidant and antibacterial activities and type of the bacteria.

\section{CONCLUSION}

The use of suitable solvents in the extraction process of leaves of $C$. Fragrans was important to consider to obtain extracts fractions which have high antioxidant and antibacterial activity for developing local $C$. fragrans Vent Willd plants as antioxidant and antibacterial medicinal ingredients.

\section{ACKNOWLEDGMENT}

I would like to thank the Directorate of Research and Community Service, Directorate General of Research and Development Strengthening and Ministry of Research and Higher Education for providing research grant with a contract No. 027/UN33.8 /LL/2018 dated February 12, 2018.

\section{REFERENCES}

1. A. Sen, P. Kar, A. Goyal and A. Das, International Journal of Green Pharmacy, 8, 210(2014), DOI: $10.4103 / 0973-8258.142671$.

2. C.T. Senjobi, T.R. Fasola and P.I.Aziba, Ife Journal of Science, 19, 141(2017), DOI:10.4314/ijs.v19i1.14.

3. M. Simorangkir, T. Barus, R. Surbakti andP. Simanjuntak, Asian Journal ofChemistry, 28, 203(2016), DOI:10.14233/ajchem.2016.19345.

4. M. Simorangkir, S. Silaban, R. Surbakti, T. Barus and P. Simanjuntak, ChimicaetNaturaActa, 5, 31(2017), DOI:10.24198/cna.v5.n1.12819.

5. M. Smallwood, 1996, Handbook of Organic Solvent Properties, John Wiley \& Sons, New York, pp. 7, 65, 227, DOI:10.1016/c2009-0-23646-4.

6. S. Sowmya and N. Lakshmidevi, International Journal of Current Research, 5, 3618 (2013).

7. Q. Zang, European Journal of Food Science and Technology, 3, 5 (2015).

8. P.S. Widyawati, T.D.W. Budianta, F.A. Kusuma and E.L. Wijaya, International Journal of Pharmacognosy and Phytochemical Research, 6, 850 (2014).

9. H. Usman, V. Iliya, H.E. Suyi and H.A. Umar, Journal of Pharmacognosy\&Phytochemistry,6, 6 (2017).

10. S. Arokiyaraj, N. Sripriya, R. Bhagya, B. Radhika, L. Prameela and N.Udayaprakash, Asian Pacific Journal of Tropical Biomedicine, 2, S601(2012), DOI:10.1016/s2221-1691(12)60281-0.

11. P.Molyneux, Songklanakarin Journal of Science and Technology, 26, 211 (2004).

12. S.L. Deore, S.S. Khadabadi, Q.R. Patel, S.P. Deshmukh. M.S. Jaju, N.R. Junghare, T.P. Wane and R.G. Jain, Rasayan Journal of Chemistry, 2,129 (2009).

13. N. Nerdy and K.Manurung, Rasayan Journal of Chemistry, 11, 1183(2018), DOI:10.31788/rjc.2018.1134018.

14. D.U.C. Rahayu, Hartono and P. Sugita, Rasayan Journal of Chemistry, 11, 762(2018), DOI: 10.31788/rjc.2018.1122076.

15. J.A.O. Olugbuyiro, A.S. Banwo, A.O. Adeyemi, O,S. Taiwo and O.A. Akintokun, Rasayan Journal of Chemistry, 11,798(2018), DOI:10.31788/RJC.2018.1121823.

16. M. Simorangkir, S.H. Saragih, B. Nainggolan and S. Silaban, In Book of Program of The ${ }^{2 n d}$ International Conference on Innovation in Education, Science and Culture (ICIESC), Medan City Indonesia, pp. 6 (2018).

17. W.W.Davis and T.R.Stout,Applied Microbiology, 22, 659 (1971).

18. A. Zapata and S. Ramirez-Arcos, Current Microbiology, 70, 907(2015), DOI: 10.1007/s00284-0150801-2. 
RASĀYAN J. Chem.

Vol. 12 | No. 2 |959 - 965| April - June | 2019

19. Y. Molla, T. Nedi, G. Tadesse, H. Alemayehu and W.Shibeshi, BMC Complementary and Alternative Medicine, 16, 287(2016), DOI: 10.1186/s12906-016-1279-6.

20. M.S. Blois, Nature, 181, 1199(1958), DOI:10.1038/1811199a0.

21. R. Devika and J. Kovilpillai, Journal of Pharmacy Research,5, 4396 (2012).

22. U.Darsana, S.N. Nair, S.K.Padinchareveetil, A.K.T.Palayullaparambil, A.K.T.Palayullaparambil, S. Juliet, R.Reghu andA.Pradeep,Research Journal of Chemical Sciences, 4, 1 (2014).

23. A. Thouri, H. Chahdoura, A.E. Arem, A.O. Hichri, R.B, Hassin andL. Achour, BMC Complementary and Alternative Medicine, 17, 248(2017), DOI: 10.1186/s12906-017-1751-y.

24. S. Sujatha and A. Suresh, Journal of Pharmaceutical and Scientific Innovation, 2, 27(2013), DOI: 10.7897/2277-4572.02333.

25. I.D. Riris, M. Simorangkir andA. Silalahi, Rasayan Journal of Chemistry, 11, 1229(2018), DOI:10.31788/rjc.2018.1133090.

[RJC-5095/2018] 